\title{
Haemophiliacs seek charges in AIDS scandal
}

Tokyo. The scandal in Japan about the supply of HIV-infected blood products to haemophiliacs in the 1980s has taken a dramatic turn with a request from a group of 217 people, made up of haemophiliacs and their relatives, for the Tokyo District Prosecutor's Office to charge a leading haemophilia specialist with "wilful negligence".

The action, which is based on the infection of two haemophiliacs with HIV, is the first attempt in Japan to institute criminal proceedings against those who were involved in the country's blood product policy during the early to mid-1980s, when nearly 2,000 haemophiliacs were infected with HIV through the use of contaminated blood coagulants.

In a legal document called a kokuhatsu jo, the group asks for charges to be made against Takeshi Abe, vice-president of Teikyo University in Tokyo, who in 1983 headed a group set up by the Ministry of Health and Welfare to help formulate policy on blood products (see Nature 367, 584; 1994).

Two civil court cases, in which almost a hundred haemophiliacs suffering from AIDS are suing the government and pharmaceutical companies, have been under way for several years in Osaka and Tokyo district courts (see Nature 364, 181; 1993). But this is the first attempt to launch criminal charges against an individual.

The group claims that although Abe knew by late 1984 that a large percentage of his patients were infected with HIV, he continued to treat uninfected patients with blood products that had not been treated with heat to kill the virus. As a result, two further patients were infected between late

\section{4 and the middle of 1985}

The group also argues that Abe was well aware by late 1984 of the potential dangers of non-heat-treated products. As a result, they say, he showed wilful negligence (mihitsu no koi) in continuing to prescribe these products to patients.

The group's case hinges on a paper that Abe published with six colleagues in the Journal of the Japan Society of Blood Transfusion in 1988 (34, p.332-339). The paper traces the appearance of antibodies to HIV in the blood samples of patients treated in Abe's department.

Among them are two cases that the paper claims showed negative results in early to mid-1985 with a variety of tests, but later became positive in all tests. The first individual was negative in tests on a blood sample collected early in June 1985, but positive in some tests for a sample collected six and a half weeks later. The second was negative in February 1985, but positive in most tests three and a half months later.

Arguing that antibodies to HIV usually appear within 8 weeks of infection, the group concludes that these two patients must have been infected sometime between early December 1984 and mid-1985.

But in August 1984, Abe sent blood samples of 48 patients to Robert Gallo of the National Cancer Institute in the United States who, together with Luc Montagnier of the Pasteur Institute in France, had discovered the virus responsible for AIDS earlier that year. The group claims that the results showed that 23 of Abe's patients were infected with HIV. According to testimony in the Tokyo District Court by Mutsuyoshi
Kazama, a colleague of Abe's at Teikyo University and a co-author of the 1988 paper, these results were known to Abe by at least 8 November 1984 , the date of the Fourth International Symposium on Haemophilia Treatment in Tokyo.

As a result of Gallo's results, the group argues that Abe must have known of the possibilities of HIV infection from nonheat-treated blood coagulants by that time. Indeed, the group argues that Abe should have been aware that HIV might be present in blood coagulants well before this, as he already had a haemophiliac patient with typical AIDS symptoms in 1983 (Nature 367, 584; 1994)

On the advice of the Tokyo District Prosecutor's office, Abe is refusing to comment on the haemophiliac group's charges. But there are a number of weaknesses in the charges. First, the identity of patients in the 1988 paper is unknown, and it is therefore not known whether the two patients referred to in the charges are alive or dead - or indeed whether they have contracted AIDS.

Second, although it is generally accepted that HIV antibodies almost invariably appear within 8 weeks of infection, there have been reports of antibodies not appearing until 3 to 6 months after infection. This would push back the date of earliest possible infection for the two cases referred to in Abe's 1988 paper, making it less certain whether infection occurred after Abe received Gallo's test results, at least in the second (earlier) case of infection.

Abe himself has long avoided commenting publicly on Japan's blood scandal. On the rare occasions that he has talked to the media, his answers have been unclear and evasive, making him an easy scapegoat for the tragedy in the Japanese press. His colleagues say he shows great care and compassion for his patients, and reject the charges against him.

But Toshihiro Suzuki, a lawyer for the haemophiliac group, says that its aim is not to put the 77-year-old Abe in jail. Rather, it wants to force an official government enquiry into the whole tragedy, which led to nearly half of Japan's 4,000 haemophiliacs being infected with HIV

The group has already appealed to the Minister of Health and Welfare to set up an investigation, but so far without response. It has therefore decided to press for criminal charges against Abe, who is at the centre of the whole affair

But a quick decision from the prosecutor's office seems unlikely. Suzuki says that only one prosecutor has been assigned to the case as the office is currently investigating numerous money scandals involving leading politicians. Furthermore, this one prosecutor has many other cases to cover.

David Swinbanks treaty, allows them to be dismissed for 